\title{
Industrial Hemp Knowledge and Interest among North Carolina Organic Farmers in the United States
}

\author{
Beatrice Dingha ${ }^{1, * \mathbb{D}}$, Leah Sandler ${ }^{2}$, Arnab Bhowmik ${ }^{1} \mathbb{D}$, Clement Akotsen-Mensah ${ }^{3}$, \\ Louis Jackai ${ }^{1}$, Kevin Gibson ${ }^{2}$ and Ronald Turco ${ }^{2}$ \\ 1 Department of Natural Resources and Environmental Design, North Carolina A\&T State University, \\ Greensboro, NC 27411, USA; abhowmik@ncat.edu (A.B.); lejackai@ncat.edu (L.J.) \\ 2 Department of Agriculture, Purdue University, 915 West State Street, West Lafayette, IN 47907, USA; \\ sandler@purdue.edu (L.S.); kgibson@purdue.edu (K.G.); rturco@purdue.edu (R.T.) \\ 3 Rutgers Agricultural Research and Extension Center, Rutgers New Jersey Agricultural Experiment Station \\ 121 Northville Rd. Bridgeton, NJ 08302, USA; ca555@scarletmail.rutgers.edu \\ * Correspondence: bndingha@ncat.edu
}

Received: 26 March 2019; Accepted: 7 May 2019; Published: 11 May 2019

check for updates

\begin{abstract}
Industrial hemp (Cannabis sativa), has been proposed as a new crop that might be of interest to organic farmers in the North Carolina and other states in the United States. However, little is known about how organic farmers view this crop. We conducted a survey among North Carolina certified organic growers to ascertain their knowledge of, and willingness to adopt, industrial hemp. Contact information was obtained from a database of certified organic farmers in North Carolina and the growers were contacted by email and directed to complete an online questionnaire. Growers were asked a wide range of questions about farm characteristics, technology adoption, interest toward industrial hemp, and policy issues regarding hemp adoption. A total of 245 farmers were contacted; 64 started the survey and 35 responded to all questions. Our results indicate that $85 \%$ of North Carolina organic growers are interested in growing hemp on their farms and the majority wanted to learn more about the crop production practices, adapted cultivars, and legality of growing it. Seventy-five percent expressed interest in being certified growers while $52 \%$ wanted to grow industrial hemp primarily for cannabidiol (CBD) oil. Most (65\%) respondents indicate they aspired to be among the first farmers in their area to grow and sell hemp. Growers who have tried new crops or new farming technology in the last three years were more likely to adopt industrial hemp production. These findings will help decision-makers understand the critical concerns of growers who are willing to adopt industrial hemp as an alternative income-generating enterprise.
\end{abstract}

Keywords: Cannabis sativa; cannabidiol; CBD oil; hemp adoption; industrial hemp; North Carolina; organic farmers

\section{Introduction}

Industrial hemp (Cannabis sativa (L.)) is one of the oldest cultivated plants in the world and is native to central-northeast Asia where its cultivation dates as far back as 5000 years ago [1]. Hemp can be grown for use as a fiber, seed, or cannabidiol (CBD) oil. It has a vast number of possible applications and has been a source of fiber and oilseed used worldwide to produce a variety of industrial and consumer products including utilization in medical therapy [2]. Hemp has been produced throughout the history of global agriculture by more than 30 countries in Europe, Asia, and North and South America currently growing industrial hemp as an agricultural commodity [3]. Worldwide, industrial hemp cultivation has been limited because it can be easily confused with marijuana that usually contains higher amounts of delta-tetrahydrocannabinol (THC). Generally, all genotypes of hemp contain the psychotropic agent 
THC, which causes a psychoactive effect when ingested by humans. Cannabis contains genetically different biotypes of both industrial (non-intoxicant) hemp and marijuana [4,5]. While industrial hemp and marijuana are the same plant (both varieties of Cannabis sativa), the legality is based on the amount of THC the plant produces. In the United States 2014 Farm Bill, the concentration of THC defines a Cannabis plant as either marijuana ( $>0.3 \% \mathrm{THC})$ or industrial hemp $(<0.3 \% \mathrm{THC})$.

Although marijuana and hemp have completely distinct purpose and applications, the fact that they belong to the same plant species (C. sativa) has created a lot of ambiguity regarding its legalization in the United States. In 2014, Congress gave states permission through the farm bill to run test programs for growing and marketing industrial hemp. Since then, 41 states including North Carolina have passed legislation that allows hemp cultivation. In North Carolina, Senate Bill 313 legalized industrial hemp production but placed limitations on its production. Industrial hemp in North Carolina must be grown for research purposes and growers must apply for a license and pay an annual fee [6]. Since 2014, there has been increasing bipartisan support, which resulted in the United States Farm Bill Act of 2018 which legalized the production of industrial hemp and allows for it to be treated like any other agricultural commodity [7]. However, regulatory uncertainty still exists even though hemp has been removed from the Controlled Substances Act, (meaning it will no longer be an illegal substance under federal law). For instance, in all states where industrial hemp has been legalized, Congress explicitly preserved the Food and Drug Administration (FDA) current authority to regulate products containing Cannabis or Cannabis-derived compounds. In North Carolina, it is unlawful to introduce food containing added CBD into interstate commerce without first obtaining FDA approval. Many companies selling CBD products are marketing them as nutraceuticals to minimize FDA involvement since the FDA does not require the same safety evaluation for nutraceuticals as it does for drugs [8].

Canada is the only current commercial industrial hemp producer in North America [9] and the United States market has been largely dependent on imports (over 90\%) from Canada $[3,10]$. The decreasing availability and rising prices of local wood fiber resources have greatly increased commercial interest in agricultural production of alternative fiber sources in the United States. Production of industrial hemp has been proposed as a viable source of substitute raw material for a wide range of industrial products including paper and composite wood products. There are numerous claims that this crop could transform the economy in a beneficial way given the growing recognition of the many uses for hemp beyond the traditional rope, cordage, and canvas. For example, in 2016, the Hemp Industries Association (HIA) reported a total retail sales of hemp products of nearly $\$ 700$ million in the United States [11]. The legalization of hemp in the United States has the potential to increase production substantially; however, research on the crop has been very limited. Most researchers acknowledge the potential profitability of the crop and the potential challenges in hemp cultivation to organic growers.

The adoption of a new technology in agriculture is at the core of agricultural growth. Unfortunately, the adoption of new agricultural technology, including new crops, is seldom rapid. Researchers have been trying to understand and explain the behavioral patterns regarding adoption of a new technology. According to [12], there are five stages through which diffusion occurs (awareness, persuasion, decision, implementation, adoption) and five categories of adopters (innovators, early adopters, early majority, late majority, and laggards). Individuals do not just adopt new technology; instead, they make a conscious decision. This process is aided by five attributes of innovation (which helps decrease uncertainty about the innovation and increase the rate of adoption) and include: Relative advantage (the degree to which an innovation is perceived as better than previous ones); compatibility (the way an innovation is consistent with existing systems and values); complexity (the perceived difficulty of an innovation to understand or use); trialability (the potential to experiment with an innovation); and observability (visibility of results of an innovation) [12,13].

The number of certified organic farms in the United States increased by $11 \%$ in $2015-2016$ and North Carolina was among the 10 top states for certified organic sales [14]. It is imperative to evaluate the perceptions and attitudes of North Carolina certified organic farmers to better understand the adoption of this new crop. Organic growers have been reported to have adoption behaviors that 
distinguish them from conventional farmers. Previous studies have shown that organic farmers have a greater awareness and concern for environmental problems associated with agriculture, greater concern about long-term sustainability, and are prepared to incur present risk for future benefits or gain $[15,16]$. In addition, organic growers are willing to adopt new farming practices and take risk to try new technologies [15]. While organic producers may be willing to accept greater risk and adopt new technologies, they also are motivated by the potential for higher profit margins associated with organic products [17]. They are also more disposed to the risks associated with the adoption decisions they make, such as accepting reduced yields for future benefits [15]. These decisions have been reported to be positively correlated with environmental concerns [18-21]. Therefore, hemp could be an ideal crop for organic farmers not only because of associated value-added products and profit generation, but it is an incredible rotation crop that would improve soil health. Since its legalization in the United States, there is much to learn about growers' perspective to make industrial hemp a viable crop that can compete with other commodities and be adopted by growers. The objective of this study was to assess organic farmers' knowledge about hemp and the factors that might influence its adoption in North Carolina with particular focus on organic hemp production.

\section{Materials and Methods}

\subsection{Sampling Population}

The population for the study comprised of North Carolina certified organic farmers whose information was obtained from the USDA Organic Integrity Database in March of 2018. This database provides data on all certified organic farmers including the certifier, certification status, operation ID, crops certified, name, address, phone number, and email address. Through this database, a search was initiated for farmers in North Carolina. Data were downloaded, scrubbed for duplicate names, and 39 farmers in the database who did not provide an email address were contacted by phone to obtain a valid email address. Overall, a total of 245 organic farmers were emailed a link to an online questionnaire developed in Qualtrics; a quantitative online research tool and software that enables survey development, distribution, and analysis. The questionnaire was developed by the researchers based on the objectives of the study and consisted of five main sections: (1) Farm and farmer characteristics (type and size of farm, number of crops, number of years farming organically, age, and gender); (2) questions designed to determine if the respondent is an early adopter of agricultural technology; (3) motivation for farming organically; (4) interest in growing hemp; and (5) conditions that would influence farmer's willingness to adopt hemp such as pest issues, crop rotations, markets, the need for specialized equipment, and additional paperwork or legal requirements. The Institutional Review Board (IRB) of North Carolina Agricultural and Technical State University (NC A\&T SU) approved this study. A weekly email reminder was sent to unfinished respondents during the course of the study (March to May 2018). Out of the 245 farmers contacted, 64 started the survey and 35 responded to all questions, giving a 55\% completion rate (number of surveys fully completed divided by the number of surveys started). These were the responses used in the data analysis for this study.

\subsection{Statistical Analyses}

All statistical analyses were conducted using JMP ${ }^{\circledR}$ Version 14.0 Pro (SAS Institute, Cary, NC, United States). A combination of single and multiple regression analyses was used to determine how farmer and farm characteristics impacted innovativeness and willingness to adopt hemp. Optimal subsets of independent variables were obtained by using the SELECTION = STEPWISE (stepwise regression) option in PROC REG to explain how respondents' demographics and reasoning for farming organically impacted their openness to hemp adoption. These are algorithms that operate by successive addition or removal of significant or non-significant terms (forward selection and backward elimination, respectively). Selection of the best models was based on the reported Akaike information criterion (AIC). We also included a Bayesian information criterion (BIC) as additional model 
testing tools [22]. Models with the smallest AICs and BICs were selected for further analysis [23-26]. Multicollinearity among variables was assessed using variation inflation factor (VIF) and if variation inflation factors were too high $(>5)$, variables were not considered to have influence over the response variable. Farm type was not a discreet variable and therefore a correlation was used to evaluate any existing correlations among farm types. A principal component analysis (PCA) was used to identify common factors that account for most of the variations in the data and was performed by examining the pattern of correlations among independent variables (i.e., questionnaire statements). The PCA allows us to confirm our hypotheses and it also determines the eigenvectors which maximize the variance. Thereafter, it attains a second linear function PC2 that is uncorrelated with PC1. The attained variables are the principal components. A PCA with varimax rotation was carried out to reduce the number of variables which could potentially influence a respondent's answers [27]. PROC ANOVA in SAS was used to determine the importance of the five attributes of innovation to the sample population. Means were separated by least significant difference at the $0.05 \%$ level when ANOVA revealed significant $(P \leq 0.05)$ differences among attributes. Descriptive statistics in MSO Excel 2016 (version 2016, Microsoft Corporation, Redmond, WA, United States) was used to calculate percentages.

\section{Results}

\subsection{Farmer and Farm Characteristics}

All survey respondents were certified organic farmers from North Carolina in the United States. The mean age of respondents was 53.4 years $\pm 2.2 \mathrm{SE}$ (values ranged from 24 to 70 years) and the median age of 57 years. Nonetheless, the majority (40\%) of survey respondents were between 60 to 69 years, 23\% between 50 to 59 years, 17\% between 40 to 49 years, and 13\% between 30 to 39 years. Our findings are similar to the average age (53 years) of organic farm operators reported in the United States in 2012 [19]. A majority (68\%) of respondents were male and $29 \%$ female and $3 \%$ provided no response. Our findings for women are similar to percentages reported [28] for organic farmers but more than the national average of $12.9 \%$ [29]. Most respondents (42\%) had at least a two or four-year college degree, $39 \%$ had a high school diploma, and $16 \%$ had a graduate degree. A majority $(65.7 \%)$ of the respondents operated farms $>30$ acres and reported gross incomes $>\$ 100,000$. Fewer than $11.4 \%$ of the respondents operated farms $<5$ acres with $\$ 10,000$ to $\$ 25,000$ in income per year. Most $(90 \%)$ of respondents own the land they farm on and a few (30\%) rent a portion of the land. The majority of respondents (61\%) indicated that their land has been certified for at least 1 to 5 years, $24 \%$ indicated for at least 6 to 10 years, and only $3 \%$ had land certified more than 15 years. On average, land was certified for six years. A majority (55\%) of the farmers were involved in vegetable and grain production.

\subsection{Factors Influencing Farmers' Willingness to Adopt Hemp}

Survey participants were asked to indicate their level of agreement to the fact that they are open to trying hemp production on their farm. Without taking any other factors into consideration, $84.8 \%$ agreed or strongly agreed that they are open to trying hemp production on their farm. In addition, majority of survey respondents indicated their interest in learning more about industrial hemp production practices and adapter cultivars $(87.9 \%)$; most agreed or strongly agreed they want to be one of the first farmers in their area to grow and sell hemp $(65 \%)$. The majority of respondents $(75 \%)$ indicated their interest in obtaining a certificate to grow hemp. Almost all (93\%) respondents indicated that knowing there are markets for certified organic hemp seeds and hemp fiber would strongly influence their willingness to grow hemp and $91 \%$ indicated they are interested in learning more about hemp markets. More than half (52\%) indicated they would grow industrial hemp primarily for CBD oil and $59.4 \%$ agreed that the ability to sell CBD oil positively influenced their willingness to grow the crop. Less than half $(46.9 \%)$ agreed that the unclear legal regulations associated with industrial hemp production would negatively influence their willingness to grow the crop and $85 \%$ agreed or strongly agreed that they are interested in learning more about the legality of growing 
hemp. Among the variables evaluated using stepwise multiple regression, 13 factors were extracted in the forward direction as those that influenced the innovativeness and willingness to adopt hemp. Of the 13 variables, inadequate knowledge and information about hemp emerged as the factors which negatively influenced the adoption of hemp to the large extent (Table 1). On the other hand, Bayesian information criterion (BIC) values showed the potential negative social attitude of the community towards hemp as the factor that would greatly impact adoption of hemp.

Table 1. Forward stepwise multiple regression of variable which influence willingness to hemp adoption. Akaike information criterion (AIC) and Bayesian information criterion (BIC) were used to select the best model.

\begin{tabular}{|c|c|c|c|c|}
\hline Step & Parameter & $P$-Value & AIC & BIC \\
\hline 1 & $\begin{array}{l}\text { Interested in obtaining certificate to begin } \\
\text { growing hemp on my farm }\end{array}$ & 0.00 & 23.28 & 23.60 \\
\hline 2 & $\begin{array}{l}\text { Interested in learning more about hemp } \\
\text { production, practices and adapted cultivars }\end{array}$ & 0.04 & 21.42 & 20.87 \\
\hline 3 & Age & 0.11 & 22.15 & 20.01 \\
\hline 4 & $\begin{array}{l}\text { I am usually not the first person in my area to } \\
\text { try a new crop, tool or practice }\end{array}$ & 0.03 & 20.27 & 15.57 \\
\hline 5 & $\begin{array}{c}\text { Personal lack of knowledge and information } \\
\text { about hemp }\end{array}$ & 0.00 & 13.46 & 4.87 \\
\hline 6 & $\begin{array}{c}\text { Not participate in the conventional } \\
\text { agriculture system }\end{array}$ & 0.04 & 14.31 & -0.08 \\
\hline 7 & Previously grown in NC & 0.07 & 18.54 & -4.51 \\
\hline 8 & $\begin{array}{l}\text { Knowing there are markets for certified organic } \\
\text { hemp seed and hemp fiber }\end{array}$ & 0.10 & 27.91 & -8.36 \\
\hline 9 & $\begin{array}{c}\text { Being one of the first farmers in my area to } \\
\text { grow and sell hemp }\end{array}$ & 0.04 & 39.69 & -17.81 \\
\hline 10 & $\begin{array}{l}\text { I am open to trying new or alternative crops, } \\
\text { practices or technology on my farm }\end{array}$ & 0.00 & 43.22 & -51.51 \\
\hline 11 & Unclear legal regulations & 0.00 & 86.13 & -85.82 \\
\hline 12 & Cash crops typically farm & 0.01 & 286.93 & -122.25 \\
\hline 13 & Use less herbicide/pesticide & 0.01 & & -180.96 \\
\hline 14 & $\begin{array}{l}\text { Potential negative social attitudes of } \\
\text { community towards crop }\end{array}$ & 0.00 & & -374.24 \\
\hline
\end{tabular}

Standard least square analysis of the output from Table 1 presented in Table 2, shows that overall, three factors significantly influenced openness to trying hemp cultivation. These are (i) interest in learning more about hemp production practices and adapted cultivars (likelihood ratio $X^{2}=12.99$; $P=0.0003$ ), (ii) interest in obtaining a certificate to grow hemp (likelihood ratio $X^{2}=6.72 ; P=0.0095$ ), and (iii) the unclear legal regulations associated with industrial hemp production (likelihood ratio $X^{2}$ $=10.53 ; P=0.0012$ ). Despite the unclear legal regulations, $84 \%$ of respondents agreed they are open to trying hemp on their farms. Table 2 also shows that personal lack of knowledge and information about hemp negatively affected respondent's willingness to grow the crop on their farms. 
Table 2. Standard least square model for variables which influence willingness to hemp adoption.

\begin{tabular}{|c|c|c|c|c|c|}
\hline Terms & Estimate & SE & $t$-Ratio & $P$ & VIF \\
\hline Intercept & 0.36 & 0.90 & 0.39 & 0.6993 & \\
\hline Cash crops typically farm & 0.00 & 0.00 & -0.21 & 0.8334 & 2.44 \\
\hline Use less herbicide/pesticide & -0.01 & 0.12 & -0.08 & 0.9374 & 3.58 \\
\hline $\begin{array}{c}\text { Not participate in the conventional agriculture } \\
\text { system }\end{array}$ & -0.10 & 0.12 & -0.82 & 0.4247 & 4.46 \\
\hline $\begin{array}{c}\text { I am open to trying new or alternative crops, } \\
\text { practices or technology on my farm }\end{array}$ & -0.03 & 0.24 & -0.14 & 0.8908 & 3.02 \\
\hline $\begin{array}{l}\text { I am usually not the first person in my area to try } \\
\text { a new crop, tool or practice }\end{array}$ & 0.16 & 0.15 & 1.11 & 0.2892 & 1.72 \\
\hline Previously grown in NC & 0.19 & 0.17 & 1.09 & 0.2945 & 1.88 \\
\hline $\begin{array}{l}\text { Interested in learning more about hemp } \\
\text { production, practices and adapted cultivars }\end{array}$ & 0.54 & 0.20 & 2.77 & 0.0159 & 8.73 \\
\hline $\begin{array}{l}\text { Interested in obtaining certificate to begin } \\
\text { growing hemp on my farm }\end{array}$ & 0.39 & 0.21 & 1.88 & 0.0829 & 13.32 \\
\hline $\begin{array}{l}\text { Being one of the first farmers in my area to grow } \\
\text { and sell hemp }\end{array}$ & -0.04 & 0.12 & -0.31 & 0.7615 & 2.88 \\
\hline $\begin{array}{c}\text { Knowing there are markets for certified organic } \\
\text { hemp seed and hemp fiber }\end{array}$ & -0.21 & 0.18 & -1.21 & 0.2474 & 3.09 \\
\hline $\begin{array}{c}\text { Personal lack of knowledge and information } \\
\text { about hemp }\end{array}$ & -0.29 & 0.20 & -1.48 & 0.1616 & 5.05 \\
\hline $\begin{array}{l}\text { Potential negative social attitudes of community } \\
\text { towards crop }\end{array}$ & -0.11 & 0.17 & -0.64 & 0.5348 & 2.08 \\
\hline Unclear legal regulations & 0.35 & 0.14 & 2.44 & 0.0300 & 3.92 \\
\hline Age & 0.001 & 0.01 & 0.13 & 0.8975 & 1.89 \\
\hline
\end{tabular}

Table 3 shows a generalized linear model analysis on participants' willingness to try hemp cultivation on their farm. The same three factors reported in Table 2 significantly influenced openness to hemp cultivation. These are (i) interest in learning more about hemp production practices and adapted cultivars (likelihood ratio $X^{2}=12.99 ; P=0.0003$ ), (ii) interest in obtaining a certificate to grow hemp (likelihood ratio $X^{2}=6.72 ; P=0.0095$ ), and (iii) the unclear legal regulations (likelihood ratio $X^{2}$ $=10.53 ; P=0.0012$ ) (prior to the 2018 Farm Bill that legalized hemp production).

Table 3. Generalized linear model analysis for variables that influence openness to hemp production.

\begin{tabular}{cccc}
\hline Terms & Estimate & $\begin{array}{c}\text { L-R Chi } \\
\text { Square }\end{array}$ & t-Ratio \\
\hline $\begin{array}{c}\text { Intercept } \\
\text { Cash crops typically farm }\end{array}$ & 0.36 & 0.33 & 0.5634 \\
Use less herbicides/pesticides & 0.00 & 0.10 & 0.7530 \\
\hline $\begin{array}{c}\text { Not participate in the conventional agriculture system } \\
\text { I am open to trying new or alternative crops, practices or }\end{array}$ & -0.01 & 0.01 & 0.9065 \\
$\quad-0.10$ & 1.43 & 0.2324 \\
I am usually not the first person in my area to try a new crop, & 0.03 & 0.04 & 0.8373 \\
$\quad \begin{array}{c}\text { tool or practice } \\
\text { Previously grown in NC }\end{array}$ & 0.19 & 2.51 & 0.1129 \\
\hline
\end{tabular}


Table 3. Cont.

\begin{tabular}{cccc}
\hline Terms & Estimate & $\begin{array}{c}\text { L-R Chi } \\
\text { Square }\end{array}$ & t-Ratio \\
\hline $\begin{array}{c}\text { Interested in learning more about hemp production, practices } \\
\text { and adapted cultivars }\end{array}$ & 0.54 & 12.99 & 0.0003 \\
$\begin{array}{c}\text { my farm } \\
\text { Interested in obtaining certificate to begin growing hemp on }\end{array}$ & 0.39 & 6.72 & 0.0095 \\
Being one of the first farmers in my area to grow and sell hemp & -0.04 & 0.21 & 0.6498 \\
Knowing there are markets for certified organic hemp seed & -0.21 & 2.99 & 0.0836 \\
$\quad$ and hemp fiber & -0.29 & 4.38 & 0.0363 \\
Personal lack of knowledge and information about hemp & -0.11 & 0.86 & 0.3531 \\
Potential negative social attitudes of community towards crop & 0.35 & 10.53 & 0.0012 \\
Unclear legal regulations & 0.00 & 0.04 & 0.8472 \\
\hline Age & & 0.07 \\
\hline
\end{tabular}

\subsection{Reasons for Farming Hemp Organically}

Without considering the other factors, nearly all respondents $(88.6 \%)$ agreed or strongly agreed that they farm organically to use less herbicides/pesticides; increase their income (88.6\%); and not use genetically modified organisms (74.3\%). Most respondents agreed or strongly agreed that other factors including receiving organic price premium (82.9\%); improving soil health, water quality, and biodiversity ( $80 \%$ ); and contribution to their community by using environmentally friendly practices $(82.4 \%)$ contribute to the reason they farm organically. In addition, $79.4 \%$ agreed or strongly agreed that they farm organically to provide healthy food for their community (73.5\%); for their family $(73.4 \%)$ and to pass down values, land, and as a way of farming to future generations (78.9\%). As described earlier, multiple regression analysis was used to examine relationships between respondents' reasoning for farming organically and their innovativeness and willingness to adopt hemp. The majority $(68.1 \%)$ of survey respondents indicated that they farm organically because they want to improve soil health, water quality, and biodiversity, and $18.4 \%$ do so to use less herbicides/pesticides (Table 4). With regards to personal financial benefits, only $4.1 \%$ of survey respondents farm organically to increase their income and just $2.8 \%$ do so to receive organic price premiums. With regard to improving health, $0.7 \%$ of respondents farm organically to provide healthy food for their communities and $0.5 \%$ do so to contribute to the local food movement. The PCA shows that two factors (i) improve soil health, water quality, and biodiversity and (ii) use less herbicides/pesticides explained about $82 \%$ of the variation, suggesting they are the two most important factors considered by respondents to farm organically (Table 4).

Table 4. Eigenvalues, percentages of explained variance, and cumulative percentages of variance for farming organically.

\begin{tabular}{cccc}
\hline Factors & Eigenvalues & Percent & Cumulative Percent \\
\hline Improve soil health, water quality and & 7.1 & 64.1 & 64.1 \\
biodiversity & 2.0 & 18.4 & 82.4 \\
Use less herbicides/pesticides & 0.6 & 5.8 & 88.3 \\
Not use GMOs & 0.5 & 4.41 & 92.4 \\
Increase my income & 0.3 & 2.8 & 95.1 \\
Receive organic price premium & 0.2 & 1.9 & 97.0 \\
Not participate in the conventional & & \\
agriculture system & &
\end{tabular}


Table 4. Cont.

\begin{tabular}{cccc}
\hline Factors & Eigenvalues & Percent & Cumulative Percent \\
\hline $\begin{array}{c}\text { Contribute to my community by using } \\
\text { environmentally friendly practices }\end{array}$ & 0.1 & 1.2 & 98.2 \\
Provide healthy food for my community & 0.1 & 0.7 & 98.9 \\
Contribute to the local food movement & 0.1 & 0.5 & 99.4 \\
$\quad \begin{array}{c}\text { Provide healthy food for my family } \\
\text { Pass down values, land, and ways of farming to } \\
\text { future generations }\end{array}$ & 0.0 & 0.4 & 99.8 \\
\hline
\end{tabular}

\subsection{Likelihood to Adopt New Technology}

Without taking any other factors into consideration, the majority $(80 \%)$ of survey respondents indicated they have tried new crops or new farming technology in the last three years. In describing their farming practices, almost all respondents (76.5\%) agreed or strongly agreed they rarely change their farming practices from year to year and all indicated they were looking for ways to improve their farms. Almost all respondents agreed or strongly agreed they were open to trying new or alternative crops, practices, or technology on their farms (97.1\%); they were usually the first person in their area to try a new crop, cultivar, or farming practice $(88.2 \%)$; that others farmers frequently asked them questions about their farming practices (88.2\%). In addition, majority of respondents indicated they respond quickly to customer interested in new products (97.1\%); and their farm size and income allows them to experiment with new crops and farming practices (79.4\%); they are usually not reluctant to try new crops or farming practices $(94.1 \%)$; and they would only try a new crop, farming practice, or technology if they see sufficient evidence that it worked (55\%). Most (73.5\%) agreed or strongly agreed that their production decisions were influenced by experts in the field such as extension educators and $87.8 \%$ did not wait to observe success from a new technology on other farms before adopting it on their own farm. Our results from the PCA (Table 5) identified three principal components that accounted for $57.1 \%$ of the variation implying these were the most important factors driving the likelihood of adopting a new technology. Figure 1 represents the factorial biplot defined by the two principal components 1 and 2 that explain $44.5 \%$ of the total variance. PC1 is the most important factor accounting for $28.8 \%$ of the variance distinguishing respondents according to those who have actually adopted or tried a new crop or new technology while PC2 accounted for 15.7\%, which stipulates the enthusiasm toward adoption of new technology.

Table 5. Eigenvalues, percentages of explained variance, and cumulative percentages of variance for likelihood to adopt new technology.

\begin{tabular}{cccc}
\hline Number & $\begin{array}{c}\text { Eigen } \\
\text { Values }\end{array}$ & Percent & Cumulative Percent \\
\hline $\begin{array}{c}\text { I have tried new crops or new farming practices in } \\
\text { the last 3 years (New_crops) }\end{array}$ & 3.7438 & 28.799 & 28.799 \\
$\begin{array}{c}\text { I am usually the first person in my area to try a new } \\
\quad \text { crop, cultivar or farming practice (First_person) }\end{array}$ & 2.0412 & 15.702 & 44.500 \\
$\begin{array}{c}\text { Other farmers frequently ask me questions about my } \\
\quad \text { farming practices (Ask_question) }\end{array}$ & 1.6361 & 12.586 & 57.086 \\
$\begin{array}{c}\text { I am usually reluctant to try new crops or farming } \\
\text { practices (Reluctant) }\end{array}$ & 1.2856 & 9.889 & 66.975 \\
\hline
\end{tabular}


Table 5. Cont.

\begin{tabular}{|c|c|c|c|}
\hline Number & $\begin{array}{l}\text { Eigen } \\
\text { Values }\end{array}$ & Percent & Cumulative Percent \\
\hline $\begin{array}{c}\text { I respond quickly to customer interest in new } \\
\text { products (Respond_quickly) }\end{array}$ & 0.9616 & 7.397 & 74.372 \\
\hline $\begin{array}{c}\text { I am always looking for ways to improve my farm } \\
\text { (Improve_farm) }\end{array}$ & 0.7792 & 5.994 & 80.366 \\
\hline $\begin{array}{l}\text { My farm size and income allows me to experiment } \\
\text { with new crops and farming practices (Experiment) }\end{array}$ & 0.7059 & 5.430 & 85.796 \\
\hline $\begin{array}{c}\text { I rarely change my farming practices from year to } \\
\text { year (Rarely_change) }\end{array}$ & 0.5373 & 4.133 & 89.929 \\
\hline $\begin{array}{l}\text { I like to wait and see if something works on other } \\
\text { farms before adopting it on my farm (Wait) }\end{array}$ & 0.3739 & 2.876 & 92.805 \\
\hline $\begin{array}{c}\text { I am open to trying new or alternative crops, } \\
\text { practices, or technologies on my farm } \\
\text { (Open_newtechnology) }\end{array}$ & 0.3627 & 2.790 & 95.595 \\
\hline $\begin{array}{l}\text { If there is enough evidence of success for a new } \\
\text { technology or crop, I will try it (Sufficient evidence) }\end{array}$ & 0.2858 & 2.199 & 97.793 \\
\hline $\begin{array}{l}\text { I am usually not the first person in my area to try a } \\
\text { new crop, tool, or practice (Not_first) }\end{array}$ & 0.1918 & 1.475 & 99.269 \\
\hline $\begin{array}{c}\text { My production decisions are influenced by experts in } \\
\text { the field such as extension educators } \\
\text { (Influence_experts) }\end{array}$ & 0.0951 & 0.731 & 100.000 \\
\hline
\end{tabular}

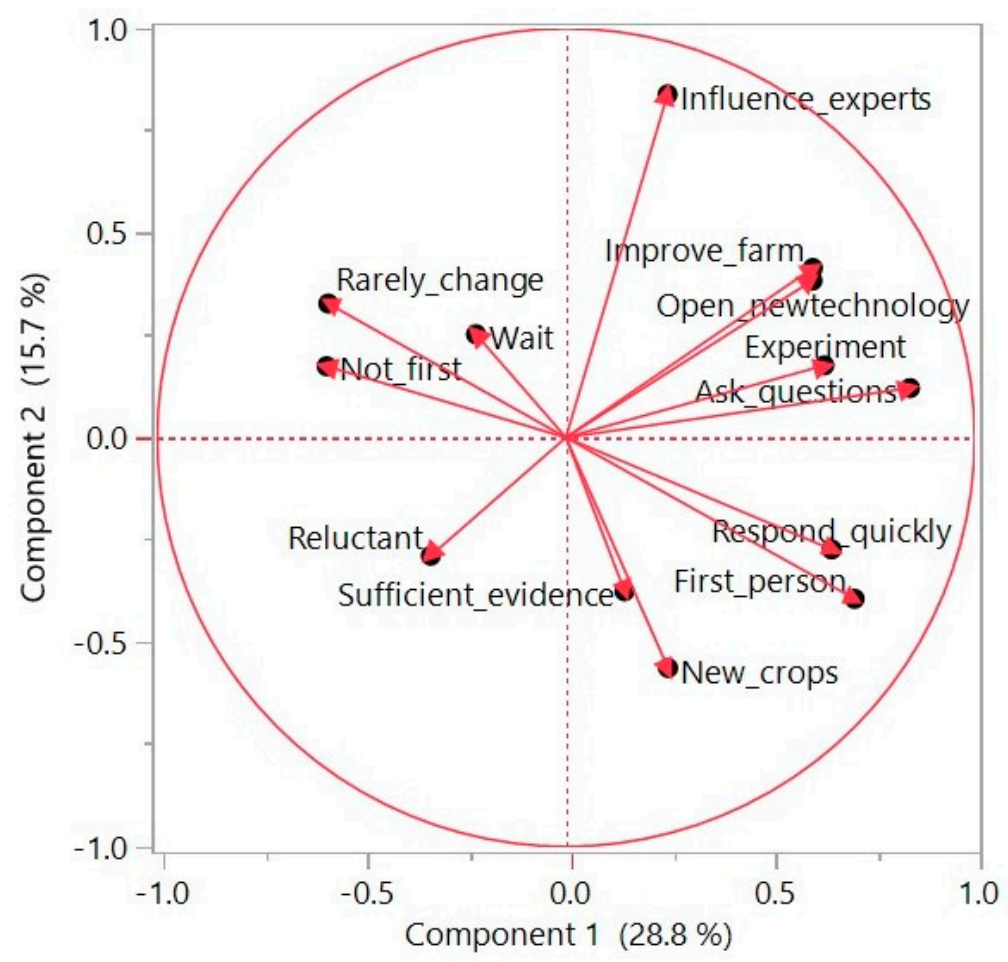

Figure 1. Principal component analysis (PCA) variables for innovative and willingness to adopt hemp parameters-projection of variables in the factor-plane, considering two factors.

\subsection{Willingness to Adopt Hemp}

Without taking any other factors into consideration majority of survey respondents indicated the following factors would positively or very positively affect their willingness to grow hemp. These include: knowing that their certifier would approve hemp as an organic crop (96.9\%); has low insect pressure (93.8\%); allows them to diversify their farm $(93.8 \%)$; knowing there are markets for 
certified organic hemp seed and hemp fiber $(93.8 \%)$; fits into crop rotation $(87.5 \%)$; competes well with weeds (84.4\%); would allow them to reach new clients or markets $(84.4 \%)$; ability to plant and or harvest hemp using existing equipment (71.9\%); able to sell at restaurants, farmers markets, and wholesale $(68.8 \%)$. About half of survey respondents indicated factors such as: lack of infrastructure in their area for processing fiber (58.1\%); need to invest in new equipment for planting and harvesting (56.3\%); had no effect to their willingness to grow hemp. A single regression equation was built to determine how the level of innovation for each farmer influenced their willingness to adopt hemp. Age and local food showed an inverse relationship as shown in Table 6. This implies that as age increases willingness to adopt hemp decreases. Also, when survey respondents farm organically because they want to contribute their produce to local food movement, their willingness to adopt hemp decreases. This might be because of the huge gaps in knowledge and infrastructure required for the crop and they are therefore not ready to venture into the unknown.

Table 6. Impact of demographics and openness to hemp adoption.

\begin{tabular}{cccccc}
\hline Factors & Estimate & SE & $t$-Ratio & $\boldsymbol{P}$ & VIF \\
\hline Intercept & 1.80 & 0.67 & 2.70 & 0.0127 & \\
Education & 0.34 & 0.10 & 3.32 & 0.0030 & 1.05 \\
Age & -0.02 & 0.01 & -2.48 & 0.0208 & 1.05 \\
Increase my income & 0.34 & 0.14 & 2.37 & 0.0264 & 1.14 \\
Contribute to the local food movement & -0.47 & 0.17 & -2.86 & 0.0089 & 2.56 \\
Pass down values, land, and ways of farming & 0.44 & 0.19 & 2.39 & 0.0255 & 2.50 \\
to future generations & & & & & \\
\hline
\end{tabular}

\subsection{Knowledge of Hemp}

Six questions (answered as either true or false or unsure) were asked to determine each farmer's knowledge of hemp. The responses indicate that $93.8 \%$ of survey respondents indicated correctly that hemp can be grown for research purposes in some states however, when asked if hemp was a perennial crop, only $18.1 \%$ answered correctly, $15 \%$ of the population were unsure, and $66.7 \%$ answered incorrectly. When asked if hemp was previously grown in North Carolina, half the population (55\%) answered correctly and $36.4 \%$ were unsure; however, $81 \%$ knew hemp is grown in Canada and Europe and only $18.8 \%$ were unsure. Ninety-four percent of respondents answered correctly that hemp can be grown for fiber and/or grain but no respondent answered correctly as to whether hemp contains large amounts of THC, the psychoactive chemical in marijuana, and $87.9 \%$ indicated it is false. Binary grading was conducted with the six questions where the correct answers were assigned a value of 1 , while incorrect answers or those that answered unsure were given a 0 . All answers were summed, calculating a single score for each farmer representing their knowledge of hemp (higher scores representing more knowledge). A single regression analysis was then used to determine how hemp knowledge impacted respondents' openness to hemp. Table 7 shows that most respondents did not know hemp is a perennial crop. Several factors that could positively or negatively impact openness to hemp are shown in Table 7. Openness to hemp decreases among respondents who know that hemp contains large amounts of THC, the psychoactive chemical that are present in high concentrations in marijuana (maybe because of the social stigma associated with the cannabis crop). There was a decrease in openness to hemp among survey respondents who were aware that hemp can be grown for fiber and seed. This is most likely because the majority of survey respondents were interested in growing hemp mainly for CBD oil. On an economic scale, the CBD oil brings the highest value of the crop's components. Openness to hemp decreases among respondents who know that it is also grown in Canada and Europe (may be due to market competition issues). 
Table 7. Multiple regression in the forward direction of previous knowledge on openness to hemp adoption.

\begin{tabular}{cccccc}
\hline Terms & Estimate & SE & $\boldsymbol{t}$-Ratio & $\boldsymbol{P}$ & VIF \\
\hline Intercept & 2.58 & 1.15 & 2.25 & 0.0339 & \\
Hemp previously grown in several states in NC & 0.17 & 0.31 & 0.57 & 0.5772 & 1.35 \\
Hemp is grown in Canada and Europe & -0.75 & 0.45 & -1.70 & 0.1030 & 1.57 \\
Is a perennial crop & 1.68 & 0.61 & 2.75 & 0.0111 & 2.96 \\
Contain large amounts of THC & -1.88 & 0.92 & -2.05 & 0.0518 & 4.32 \\
Can be grown for research & 1.00 & 0.62 & 1.62 & 0.1193 & 1.35 \\
Can be grown for fiber and grain & -1.38 & 0.98 & -1.40 & 0.1738 & 3.41 \\
\hline
\end{tabular}

\subsection{Five Attributes of Innovation as Perceived to Apply to Hemp}

For each respondent, a score for the five attributes of innovation was calculated. The survey contained a set of 20 questions regarding aspects of hemp production that correlated with these attributes and included: (i) Relative advantage (diversify farm, knowing there are markets for certified organic hemp seed and hemp fiber, competes well with weeds, has low insect pressure, can reach new clients or markets, and ability to sell CBD) oil; (ii) compatibility (fits into current rotation, knowing certifier would approve hemp as an organic crop, is able to sell at restaurants, farmers markets, and wholesale, and ability to plant and or harvest hemp using existing equipment); (iii) observability (being one of the first farmers in my area to grow and sell hemp, potential negative social attitudes of community toward crop, could negatively impact ones reputation); (iv) trialability (small number of markets to sell products, personal lack of knowledge and information about hemp, extension educators are knowledgeable about growing hemp); and (vi) complexity (having to send tissue samples to the state chemist each year to be tested for THC, seed only available from international seed companies, lack of infrastructure for processing fiber, need to invest in new equipment for planting and harvesting, and unclear legal regulations). Answers for all questions that corresponded with each attribute were averaged thus assigning each respondent a score for each attribute. A cumulative score was averaged for each attribute to determine how the surveyed population valued each attribute of innovation.

There was significant difference among the five attributes with complexity and trialability being the most important attributes of innovation of hemp production (Table 8). This includes factors of concern to respondents such as personal lack of knowledge and information about hemp, the fact that tissue samples have to be tested for THC, seeds can only be obtained from international seed companies, the lack of infrastructure for processing fiber, the need to invest in new equipment for planting and harvesting, and unclear legal regulations. Relative advantage and compatibility were the least valued attributes of innovation to hemp production. This included factors that would provide additional benefit to the respondents such as the fact that hemp allows grower to diversify their farm production, it fits into current crop rotation, and knowing that the crop is able to sell at restaurants, farmers markets, and wholesale; furthermore, the ability to plant and/or harvest hemp using existing equipment and knowing that the certifier would approve hemp as an organic crop; as well as knowing that there are markets for certified organic hemp seed and hemp fiber, its ability to compete well with weeds coupled with low insect pressure, and ability to sell CBD oil. 
Table 8. Mean $( \pm$ SE) of five attributes of innovation as perceived to apply to hemp.

\begin{tabular}{cc}
\cline { 2 - 3 } Attributes & Means \pm SE \\
\cline { 2 - 3 } Compatibility & $1.84 \pm 0.10 \mathrm{c}$ \\
Observability & $2.77 \pm 0.09 \mathrm{~b}$ \\
Complexity & $3.38 \pm 0.13 \mathrm{a}$ \\
Relative advantage & $1.66 \pm 0.08 \mathrm{c}$ \\
Trialability & $3.03 \pm 0.12 \mathrm{ab}$ \\
$F$ & 52.3 \\
$P$ & $<0.000$ \\
$d f$ & 4,155 \\
\hline
\end{tabular}

Means within a column followed by the same letter are not significantly different at $P \leq 0.05$.

\section{Discussion}

In the United States, industrial hemp production is controlled under drug enforcement laws. To grow industrial hemp in the United States, the farmer must obtain a permit from the Drug Enforcement Agency (DEA). Despite this regulation at the time the survey was administered (pre-legalization to grow industrial hemp in the United States, Farm Bill Act, 2018), there was a high likelihood that industrial hemp would be adopted by North Carolina organic farmers. To the best of our knowledge, this is the first study in North Carolina to ascertain knowledge and willingness of organic growers regarding industrial hemp. The majority of organic farmers in this study indicated several factors that influenced their decision to grow organically; these reasons are in alignment with several other studies which have also concluded that growers adopt organic farming because they want to increase their income [15,17,19,30-33]; reduce herbicide/pesticide use [34]; improve soil health, water quality, and biodiversity and as a lifestyle $[17,35,36]$; provide healthy food for their community and for their family $[37,38]$; and contribute to their community by using environmentally friendly practices [19].

Our survey shows that organic farmers who have tried new crops or new farming technology in the last three years are more likely to adopt hemp. These highly innovative individual (innovators) are likely to be imitated by a larger group of people (early adopters) who would adopt only when they are certain of the innovation's potential benefits. Early adopters tend to have greater knowledge about the benefits of a technology and are usually committed to sharing crop know-how with others [39]. On the other hand, late adopters wait to obtain information from early adopters [40]. However, while most growers are willing to share information and learn from other growers a valuable crop such as hemp may cause farmers to keep innovation information closely guarded to maintain a competitive advantage. Our results show that over $50 \%$ of respondents would try a new crop, farming practice, or technology if they see sufficient evidence that it worked somewhere. If we assume that farmers who are willing to adopt technologies early will be lead farmers, then our findings will suggest that organic growers in North Carolina will be willing to adopt hemps if they find out that there are some farmers already growing it.

The decision to adopt, or not to adopt, is influenced by the knowledge and perception of the potential adopter towards the innovation. Farmers can have knowledge about the existence of a new technology, how to apply it, and what the outcomes are in terms of products, yield, potential environmental benefits, risks, and costs. This information then forms the basis of the perceptions and attitudes these individuals develop towards the technology. Therefore, a positive attitude towards an agricultural innovation will increase the likelihood of adoption and a negative attitude will reduce the probability of adoption. We have demonstrated in this study that organic growers in North Carolina were concerned about personal lack of knowledge and information about hemp (lack knowledge that hemp is a perennial crop, hemp contains large amount of THC, etc.) and indicated this would negatively affect their willingness to grow the crop on their farms. Similarly, smallholder farmers in western Tanzania indicated that the main obstacle influencing adoption of improved fallow practices 
was lack of awareness or poor knowledge [41]. Innovations that can be tried on a small scale prior to full implementation are more likely to be adopted. Our results show the existence of a gap in knowledge on hemp and the need for extension services to disseminate the necessary information to farmers and set up demonstration plots in North Carolina and elsewhere. There is enthusiasm to acquire knowledge regarding industrial hemp as $87.9 \%$ of survey respondents indicated their interest in learning more about hemp production practices and adapted cultivars. In addition, $75 \%$ of respondents are interested in obtaining a certificate to begin hemp cultivation. The lack of knowledge for this crop is very concerning. For example, growers need to know simple information such as the fact that while seed and fiber hemp plants can be grown close together and harvested with most traditional equipment, CBD-producing plants, much like their THC-producing cousins, have to be planted at wider intervals and have to be harvested by hand. The role of extension in training is crucial in the development of knowledge, perceptions, and attitudes about agricultural innovations.

Generally, innovations that offer more relative advantage, compatibility, simplicity, trialability, and observability will be adopted faster than other innovations [12] The relative advantage and observability of an innovation represents the immediate and long-term economic benefits from using it, whereas compatibility, complexity, and trialability are indicators of the ease with which a potential adopter can learn about and use an innovation [42]. Complexity and trialability were the most important attributes of innovation of hemp production from this study. Several other factors, including the fact that tissue samples have to be tested for THC, (the principal intoxicant cannabinoid), seeds can only be obtained from international seed companies, the lack of infrastructure for processing fiber, the need to invest in new equipment for planting and harvesting, and unclear legal regulations were some of the issues growers wanted addressed before adoption. Relative advantage, compatibility, observability, and trialability were factors that significantly affected adoption of integrated pest management (IPM) practices [43]. One study found that additional beneficial IPM practices such as economic profitability, decreasing production cost, and effort saving would greatly influence farmers' decision to adopt technology [44]. Relative advantage was the most significant factor affecting adoption of alfalfa (lucerne) into a pastoral management system [45]; as with the adoption of new legumes [46,47]; and the adoption of conservation practices [48,49]. Support programs that are based on yield tended to increase the relative advantage of the intensification of farming and thus increase adoption and use of herbicides [50,51]. In the United States, farmers have rapidly adopted genetically modified crops since their introduction in the mid-1990s as a result of the numerous benefits (including higher yields, lower costs as a result of reduced pesticide use, and ease of management) it provides to growers [52].

Industrial hemp production in North Carolina is not straightforward and involves a series of steps that include applying and obtaining a North Carolina grower license to start. Industrial hemp growers are required to work with university researchers and are compelled to report their data, information, and results to the institution. The law requires the research program consist primarily of demonstration plots planted and cultivated by select growers. However, farmers are encouraged to make comparisons between varieties, practices, planting dates, harvest dates, or other variables. The potential negative social attitude of the community towards hemp is likely to have a slowing of industrial hemp adoption. This stems mainly from the stigma of producing cannabis, which is different from industrial hemp. Organic growers are justified in being reluctant to adopt hemp because hemp has historically been given negative publicity and therefore production was banned in Western world in the early 20th century because most biotypes had high THC [53]. Although hemp is the main source of THC, there are many other important attributes of hemp. In Central Asia, where this herbaceous plant originated, hemp has been used in folk medicine and as a source of textile fiber since the dawn of times and as a fast-growing plant it has recently seen a resurgence of interest because of its multi-purpose applications including high levels of phytochemicals and a rich source of both cellulosic and woody fibers. Hemp is used extensively in pharmaceuticals and in the construction sector, since its metabolites show potent bioactivities in human health. Its outer and inner stem tissues can be used to make bioplastics and concrete-like material [53]. 
From our study, younger farmers may be more willing to adopt hemp. This supports several other studies which have concluded that older farmers are less likely to be early innovation adopters than younger farmers [21,54,55]. Adoption of the crop by the younger farmers may be attributed to the fact that young farmers may be interested in capitalizing on the booming consumer demand for local and sustainable food and are more likely to grow organically. It could also be that young farmers are more educated and willing to learn compared to older farmers. Education is a factor that has a bearing on adoption of agricultural technologies. Some technologies are more knowledge-intensive than others. Farmers with higher education have better access to information that is beneficial to farming operation. They also tend to possess higher analytic comprehension of the information necessary to successfully implement new technology. In this study, the number of years of formal education appears to have no influence on the willingness regarding adoption of hemp production. Almost all respondents had at least a high school diploma. In other studies, involving the adoption of legume cover crop [56] and fertilizer and hybrid seeds by maize growers [57], a positive association was reported between education and age. Another study by [58] found education to have a negative influence on adoption of tree-based fodder technologies. Education was reported to be negatively correlated with adoption of conservation tillage for farmers in Wisconsin in the United States [59].

Hemp is traditionally grown for either seed or fiber. The seeds contain approximately $30 \%$ protein, $25 \%$ starch, and $30 \%$ oil $[60,61]$. Opportunities for hemp production have increased with the recognition that the crop can be grown for different uses not only for fibers, but also for the seed and oils. From our study of organic growers in North Carolina, $52 \%$ of the growers indicated they would grow industrial hemp primarily for CBD oil and $59.4 \%$ agreed that the ability to sell CBD oil positively influenced their willingness to grow the crop. The presence of well-established markets for crops and produce grown by farmer would contribute to decreasing the uncertainty and risk [62]. The global industrial hemp market size is estimated to be 10.6 billion in 2025. Total sales for the United States hemp industry in 2017 were $\$ 820$ million and this was boosted by explosive growth in the hemp-derived CBD oil. Given the presence of a market for the crop, it is not surprising that from our study, respondents indicated that the willingness to grow industrial hemp was influenced by the presence of ready markets for certified organic hemp seeds and fiber. The industry is experiencing this growth as a result of increasing consumer awareness pertaining to benefits associated with hemp products. Growth of industrial hemp is expected to escalate even more in the light of the recent legalization nationwide of the 2018 Farm Bill. Growing hemp primarily for CBD oil could be a reflection of the fact that as a new crop, growers are less interested in the diversity the crop has to offer but would rather focus on an aspect, for example CBD oil, which they perceived would be more profitable. The observed responses could also be attributed to the fact that hemp produces over 100 known cannabinoids, most notably CBD [63], and in the United States, clinical trials are ongoing to investigate CBD for treatment of several medical conditions [64]. Moreover, CBD has been granted orphan drug status for some conditions [64]. With the use for CBD oil on the rise in the United States and the hemp industry projected to reach $\$ 1$ billion dollar in 2018 as a result of hemp-derived CBD oil, most growers may want to create a niche for this crop.

Author Contributions: Conceptualization, K.G. and R.T.; formal analysis, B.D. and C.A.-M.; funding acquisition, K.G.; methodology, L.S. and K.G.; writing—original draft, B.D.; writing—review and editing, B.D., L.S., A.B., C.A.-M., L.J., K.G., and R.T.

Funding: This research was funded by Purdue University Diversity Transformation Collaboration Mini-Grant program. Publication charges were paid by the Agricultural Research Program, College of Agriculture and Environmental Sciences, NCA\&T State University.

Acknowledgments: The authors would like to thank Marsha E Heffner for the support in contacting survey participants.

Conflicts of Interest: The authors declare no conflict of interest. 


\section{References}

1. Kraenzel, D.G.; Petry, T.; Nelson, B.; Anderson, M.J.; Mathern, D.; Todd, R. Industrial Hemp as an Alternative Crop in North Dakota: A White Paper Study of the Markets, Profitability, Processing, Agronomics and History; Agricultural Economics Report No. 402; The Institute for Natural Resources and Economic Development, North Dakota State University: Fargo, ND, USA, 1998.

2. Amaducci, S.; Scordia, D.; Liu, F.H.; Zhang, Q.; Guo, H.; Testa, G.; Cosentino, S.L. Key cultivation techniques for hemp in Europe and China. Ind. Crop. Prod. 2015, 68, 2-16. [CrossRef]

3. Johnson, R. Hemp as an Agricultural Commodity. Congressional Research Service. Available online: http://nationalaglawcenter.org/wp-content/uploads/assets/crs/RL32725.pdf (accessed on 3 March 2019).

4. Small, E. Evolution and Classification of Cannabis sativa (Marijuana, Hemp) in Relation to Human Utilization. Bot. Rev. 2015, 81, 189-294. [CrossRef]

5. Small, E. Cannabis: A Complete Guide; CRC Press, Taylor and Francis Group: Boca Raton, FL, USA, 2016; 597p.

6. North Carolina Department of Agriculture and Consumer Services. Industrial Hemp Pilot Program in North Carolina. Available online: https://www.ncAgric.gov/hemp/ (accessed on 16 January 2019).

7. National Conference of State Legislatures. State Industrial Hemp Status. Available online: http://www. ncsl.org/research/agriculture-and-rural-development/state-industrial-hemp-statutes.aspx (accessed on 17 February 2019).

8. Malone, T.; Gomez, K. Hemp in the United States: A Case Study of Regulatory Path Dependence. Appl. Econ. Perspect. Policy 2019, 1-16. [CrossRef]

9. Cherney, J.; Small, E. Industrial Hemp in North America: Production, Politics and Potential. Agronomy 2016, 6, 58. [CrossRef]

10. Small, E.; Marcus, D. Hemp-A new crop with new uses for North America. In Trends in New Crops and New Uses; Janick, J., Whipkey, A., Eds.; ASHS Press: Alexandria, Egypt, 2002; pp. 284-326.

11. Vote Hemp. 2016 Annual Retail Sales for Hemp Products Estimated at \$688 Million. Available online: https://www.votehemp.com/press_releases/2016-annual-retail-sales-hemp-products-estimated-688million/ (accessed on 6 March 2019).

12. Rogers, E.M. Diffusion of Innovations, 5th ed.; Free Press: New York, NY, USA, 2003; p. 551.

13. Sarcheshmeh, E.E.; Bijani, M.; Sadighi, H. Adoption behavior towards the use of nuclear technology in agriculture: A causal analysis. Technol. Soc. 2018, 55, 175-182. [CrossRef]

14. UDSA-NASS. 2016 Certified Organic Survey. 2017. Available online: https://www.nass.usda.gov/ Publications/Highlights/2017/2016_Certified_Organic_Survey_Highlights.pdf (accessed on 25 April 2019).

15. McCann, E.; Sullivan, S.; Erickson, D.; DeYoung, R. Environmental awareness, economic orientation, and farming practices: A comparison of organic and conventional farmers. Environ. Manag. 1997, 21, 747-758. [CrossRef]

16. Läpple, D. Comparing attitudes and characteristics of organic, former organic and conventional farmers: Evidence form Ireland. Renew. Agric. Food Syst. 2012, 28, 329-337. [CrossRef]

17. Peterson, H.H.; Barkley, A.; Chacon-Cascante, A.; Kastens, T.L. The motivation for organic grain farming in the United States: Profits, lifestyle, or the environment? J. Agric. Appl. Econ. 2012, 44, 137-155. [CrossRef]

18. Best, H. Environmental concern and the adoption of organic agriculture. Soc. Nat. Resour. 2010, 23, 451-468. [CrossRef]

19. Kaufmann, P.; Zemeckis, R.; Skulskis, V.; Kairyte, E.; Stagl, S. The diffusion of organic farming in Lithuania. J. Sustain. Agric. 2011, 35, 522-549. [CrossRef]

20. Läpple, D. Adoption and abandonment of organic farming: An empirical investigation of the Irish Drystock sector. J. Agric. Econ. 2010, 61, 697-714. [CrossRef]

21. Läpple, D.; Van Rensburg, T. Adoption of organic farming: Are there differences between early and late adoption? Ecol. Econ. 2011, 70, 1406-1414. [CrossRef]

22. Schawrz, G. Estimating the dimension of a model. Ann. Stat. 1978, 6, 461-464. [CrossRef]

23. Wikipedia, F. Bayesian information criterion. Biometrics 2000, 56, 256-262.

24. Freund, R.J.; Littell, R.C. SAS System for Regression, 3rd ed.; SAS Institute: Cary, NC, USA, 2000; p. 256.

25. Littell, R.C.; Stroup, W.W.; Freund, R.J. SAS System for Linear Models, 3rd ed.; SAS Institute: Cary, NC, USA, 2002. 
26. Rao, K.S. The Basics of Financial Econometrics: Tools, Concepts, and Asset Management Applications. Quant. Financ. 2015, 15, 1773-1775. [CrossRef]

27. Peck, J.E. Multivariate Analysis for Ecologists: Step-by-Step, 2nd ed.; MjM Software Design: Gleneden Beach, OR, USA, 2016; p. 192.

28. National Sustainable Agriculture Coalition Census Drilldown. Available online: http://sustainableagriculture. net/blog/2012-census-organic-local/ (accessed on 5 January 2019).

29. Prager, D.; Williamson, J. Farm Household Income and Characteristics. Unites States Department of Agriculture Economic Research Service. Available online: https://www.ers.usda.gov/data-products/farmhousehold-income-and-characteristics (accessed on 2 March 2019).

30. Constance, D.H.; Choi, J.Y. Overcoming the barriers to organic adoption in the United States: A look at pragmatic conventional producers in Texas. Sustainability 2010, 2, 163-188. [CrossRef]

31. Flaten, O.; Lien, G.; Ebbesvik, M.; Koesling, M.; Valle, P.S. Do the new organic producers differ from the 'old guard'? Empirical results from Norwegian dairy farming. Renew. Agric. Food Syst. 2006, 21, 174-182. [CrossRef]

32. Padel, S. Conversion to organic farming: A typical example of the diffusion of an innovation? Sociol. Rural. 2001, 41, 40-61. [CrossRef]

33. Sgroi, F.; Candela, M.; Trapani, A.; Foderà, M.; Squatrito, R.; Testa, R.; Tudisca, S. Economic and financial comparison between organic and conventional farming in Sicilian lemon orchards. Sustainability 2015, 7, 947-961. [CrossRef]

34. Cranfield, J.; Henson, S.; Holliday, J. The motives, benefits, and problems of conversion to organic production. Agric. Hum. Values 2010, 27, 291-306. [CrossRef]

35. Koesling, M.; Flaten, O.; Lien, G. Factors influencing the conversion to organic farming in Norway. Int. J. Agric. Resour. Gov. Ecol. 2008, 7, 78-95. [CrossRef]

36. Rigby, D.; Cáceres, D. Organic farming and the sustainability of agricultural systems. Agric. Syst. 2001, 68, 21-40. [CrossRef]

37. Kallas, Z.; Serra, T.; Gil, J.M. Farmers' objectives as determinants of organic farming adoption: The case of Catalonian vineyard production. Agric. Econ. 2010, 41, 409-423. [CrossRef]

38. Sarker, M.A.; Itohara, Y. Factors Influencing the Extent of Practice of Organic Farming Technologies: A Case Study of Tangail District in Bangladesh. Am. J. Agric. Biol. Sci. 2008, 3, 584-590. [CrossRef]

39. Llewellyn, R.S. Information quality and effectiveness for more rapid adoption decisions by farmers. Field Crop. Res. 2007, 104, 148-156. [CrossRef]

40. Lamb, D.W.; Frazier, P.; Adams, P. Improving pathways to adoption: Putting the right P's in precision agriculture. Comput. Electron. Agric. 2008, 61, 4-9. [CrossRef]

41. Matata, P.; Ajay, O.C.; Oduol, P.A.; Agumya, A. Socio-economic factors influencing adoption of improved fallow practices among smallholder farmers in western Tanzania. Afr. J. Agric. Res. 2010, 5, 818-823.

42. Boz, I.; Akbay, C. Factors influencing the adoption of maize in Kahramanmaras province of Turkey. Agric. Econ. 2005, 33, 431-440. [CrossRef]

43. Bodnaruk, K.; Frank, B. Factors influencing the acceptance of IPM in the Australian apple industry. In Proceedings of the 2nd Australasia Pacific Extension Conference, Albury, Australia, 18-21 November 1997; pp. 232-238.

44. Miller, D.; Meek, F. Cost and efficacy comparison of integrated pest management strategies with monthly spray insecticide applications for German cockroach control in public housing. J. Econ. Entomol. 2004, 97, 559-569. [CrossRef]

45. Curtis, A.; MacKay, J.; Van Nouhuys, M.; Lockwood, M.; Byron, I.; Graham, M. Exploring Landholder Willingness and Capacity to Manage Dryland Salinity: The Goulburn Broken Catchment; Johnstone Centre, Charles Sturt University: Albury, Australia, 2000.

46. Abadi Ghadim, A.K.; Pannell, D.J.; Burton, M.P. Risk, uncertainty and learning in adoption of a crop innovation. Agric. Econ. 2005, 33, 1-9. [CrossRef]

47. Marsh, S.; Pannell, D.; Lindner, R. The impact of agricultural extension on adoption and diffusion of lupins as a new crop in Western Australia. Aust. J. Exp. Agric. 2000, 40, 571-583. [CrossRef]

48. Cary, J.W.; Wilkinson, R.L. Perceived profitability and farmers' conservation behaviour. J. Agric. Econ. 1997, 48, 13-21. [CrossRef] 
49. Sinden, J.A.; King, D.A. Adoption of soil conservation measures in Manilla Shire, New South Wales. Rev. Mark. Agric. Econ. 1990, 58, 179-192.

50. Helms, G.L.; Bailey, D.; Glover, T.F. Government programs and adoption of conservation tillage practices on nonirrigated wheat farms. Amer. J. Agric. Econ. 1987, 69, 786-795. [CrossRef]

51. Miranowski, J.A.; Hrubovak, J.; Sutton, J. The effects of commodity programs on resource use. In Commodity and Resource Policies in Agricultural Systems; Bockstael, N., Just, R., Eds.; Springer: New York, NY, USA, 1991.

52. Carpenter, J.; Gianessi, L. Why US farmers have adopted genetically modified crops and the impact on US agriculture. AgBiotechNet 2001, 3, 1-5.

53. Andre, C.M.; Hausman, J.F.; Guerriero, G. Cannabis sativa: The plant of the thousand and one molecules. Front. Plant Sci. 2016, 7, 17. [CrossRef]

54. Diederen, P.; van Meijl, H.; Wolters, A.; Bijak, K. Innovation, adoption in agriculture: Innovators, early adopters and laggards. Cahiers d'Economie et de Sociologie Rurales 2003, 67, 30-50.

55. Knowler, D.; Bradshaw, B. Farmer's adoption of conservation agriculture: A review and synthesis of recent research. Food Policy 2007, 32, 25-48. [CrossRef]

56. Ekepu, D.; Tirivanhu, P. Assessing socio-economic factors influencing adoption of legume-based multiple cropping systems among smallholder sorghum farmers in Soroti, Uganda. S. Afr. J. Agric. Ext. 2016, 44, 195-215. [CrossRef]

57. Chirwa, E.W. Adoption of fertiliser and hybrid seeds by smallholder maize farmers in Southern Malawi. Dev. S. Afr. 2005, 22, 1-12. [CrossRef]

58. Jera, R.; Ajayi, O.C. Logistic modelling of smallholder livestock farmers' adoption of tree-based fodder technology in Zimbabwe. Agrekon 2008, 47, 378-392. [CrossRef]

59. Gould, B.W.; Saupe, W.E.; Klemme, R.M. Conservation tillage: The role of farm and operator characteristics and the perception of soil erosion. Land Econ. 1989, 65, 167-182. [CrossRef]

60. Callaway, J.C. Hempseed as a nutritional resource: An overview. Euphytica 2004, 140, 65-72. [CrossRef]

61. Galasso, I.; Ponzoni, E. In Silico Exploration of Cannabis sativa L. Genome for Simple Sequence Repeats (SSRs). Am. J. Plant Sci. 2015, 6, 7. [CrossRef]

62. Epplin, F.M.; Clark, C.D.; Roberts, R.K.; Hwang, S. Challenges to the development of a dedicated energy crop. Am. J. Agric. Econ. 2007, 89, 1296-1302. [CrossRef]

63. Mehmedic, Z.; Chandra, S.; Slade, D.; Denham, H.; Foster, S.; Patel, A.S.; Ross, S.A.; Khan, I.A.; ElSohly, M.A. Potency trends of $\triangle 9$-THC and other cannabinoids in confiscated cannabis preparations from 1993 to 2008. J. Forensic Sci. 2010, 55, 1209-1217. [CrossRef]

64. Schluttenhofer, C.; Yuan, L. Challenges towards Revitalizing Hemp: A Multifaceted Crop. Trends Plant Sci. 2017, 22, 917-929. [CrossRef]

(C) 2019 by the authors. Licensee MDPI, Basel, Switzerland. This article is an open access article distributed under the terms and conditions of the Creative Commons Attribution (CC BY) license (http://creativecommons.org/licenses/by/4.0/). 